\title{
CYTOTOXICITY OF STEM EXTRACTS OF SELECTED CASSIA SPECIES AGAINST HELA AND BREAST CANCER CELL LINES IN VITRO
}

\author{
SUREKHA R DESHPANDE ${ }^{1}$, SHANKAR NAIK B ${ }^{2 *}$ \\ ${ }^{1}$ Department of Zoology, Basaveshwar Science College, Bagalkot - 587 101, Karnataka, India. ${ }^{2}$ Department of Biology, Government Science \\ College, Chikmagalur - 577 101, Karnataka, India. Email: shankar_sbn@yahoo.co.in
}

Received: 02 April 2016, Revised and Accepted: 01 December 2016

\section{ABSTRACT}

Objective: The use of plants for medicinal remedies is an integral part of the Indian cultural life, and the traditional background of Indian medicine shows widespread use of plant products in cancer treatment. In this study, stem extracts of some selected Cassia species have been evaluated for their cytotoxic activities under in vitro conditions.

Methods: The stems were shade dried at room temperature. The dried and coarsely powdered plant material were extracted with petroleum ether $\left(60-80^{\circ} \mathrm{C}\right)$, chloroform, and ethanol using soxhlet apparatus. The cytotoxicity was evaluated by [3-(4,5-dimethylthiazol-2-yl)-2,5-diphenyltetrazolium bromide] assay.

Results: Stem extracts of three Cassia species, viz., Cassia glauca, Cassia Obtusifolia, and Cassia sophera have been evaluated for their cytotoxic activities with chloroform, ethanol and pet ether against HeLa and breast cancer cell lines. Among the three different solvents used at different concentrations,

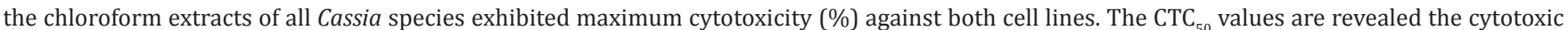

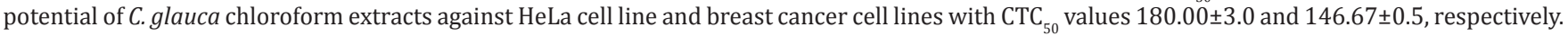
Chloroform extracts of $C$. Obtusifolia and $C$. sophera showed maximum activity against HeLa (380.00 \pm 1.1 and $800.00 \pm 1.7$, respectively) and breast cancer cell lines (310.00 \pm 1.1 and $633.33 \pm 0.6)$.

Conclusion: The results of this study demonstrate the potent cytotoxic activity of chloroform extracts of stems of Cassia species against HeLa and Breast cancer cell lines.

Keywords: Cassia, 3-(4,5-dimethylthiazol-2-yl)-2,5-diphenyltetrazolium bromide, Cytotoxicity, HeLa, Breast cancer.

(C) 2017 The Authors. Published by Innovare Academic Sciences Pvt Ltd. This is an open access article under the CC BY license (http://creativecommons. org/licenses/by/4. 0/) DOI: http://dx.doi.org/10.22159/ajpcr.2017.v10i3.11991

\section{INTRODUCTION}

Plant and plant products both as extracts and derived compounds are known to be effective and versatile chemopreventive agents against a variety of types of cancers [1]. About $60 \%$ of currently used anticancer agents are derived from natural sources directly or indirectly [2]. Development of several promising new agents in anticancer drug therapy such as vinblastine, vincristine, the camptothecin derivatives, topotecan and irinotecan, etoposide along with flavopiridol and combretastain A4 phosphate from natural sources stimulated renewed interest among the biologists in screening the medicinal plants in anticancer drug therapy $[3,4]$. The use of plants for medicinal remedies is an integral part of the Indian cultural life, and the traditional background of Indian medicine shows widespread use of plant products in cancer [5,6]. The members of Cassia species are rich sources of polyphenols, anthraquinone derivatives, flavonoids, and polysaccharides $[7,8]$, and they have been found to exhibit antiinflammatory, antioxidant, hypoglycemic, antiplasmodial, larvicidal, antimutagenic, and anticancer activities [9]. In this study, stem extracts of some selected Cassia species have been evaluated for their cytotoxic activities under in vitro conditions.

\section{METHODS}

Plant material and stem extraction

The stems of Cassia glauca, Cassia obtusifolia, and Cassia sophera were collected from in and around Bagalkot District of North Karnataka region of Southern India. The stems were shade dried at room temperature. The dried and coarsely powdered plant material was extracted with petroleum ether $\left(60-80^{\circ} \mathrm{C}\right)$, chloroform and ethanol using soxhlet apparatus. The extracts wee dried under reduced pressure at temperature at $30^{\circ} \mathrm{C}$ to dryness to yield dried extract residue.

\section{Cell lines and culture medium}

HeLa and MDA MB 231 (breast cancer) cell lines were procured from National Centre for Cell Sciences, Pune, India. Stock cells were cultured in DMEM supplemented with $10 \%$ inactivated fetal bovine serum (FBS), penicillin $(100 \mathrm{IU} / \mathrm{ml})$, streptomycin $(100 \mathrm{mg} / \mathrm{ml})$, and amphotericin $\mathrm{B}(5 \mathrm{mg} / \mathrm{ml})$ in an humidified atmosphere of $5 \% \mathrm{CO}_{2}$ at $37^{\circ} \mathrm{C}$ until confluent. The cells were dissociated with trypsin phosphate versene glucose solution $(0.2 \%$ trypsin, $0.02 \%$ ethylenediaminetetraacetic acid, $0.05 \%$ glucose in phosphate-buffered saline [PBS]). The stock cultures were grown in $25 \mathrm{~cm}^{2}$ culture flasks, and all experiments were carried out in 96 microtitre plates (Tarsons India Pvt. Ltd., Kolkata, India).

\section{Preparation of test solutions}

For cytotoxicity studies, each weighed test drugs were separately dissolved in distilled dimethyl sulfoxide and volume was made up with DMEM supplemented with $2 \%$ inactivated FBS to obtain a stock solution of $1 \mathrm{mg} / \mathrm{ml}$ concentration and sterilized by filtration. Serial two-fold dilutions were prepared from this for carrying out cytotoxic studies.

Determination of cell viability by 3-(4,5-dimethylthiazol-2-yl)-2,5diphenyltetrazolium bromide (MTT) assay

The monolayer cell culture was trypsinized, and the cell count was adjusted to $1.0 \times 10^{5}$ cells $/ \mathrm{ml}$ using DMEM containing $10 \%$ FBS. To each well of the 96 well microtitre plate, $0.1 \mathrm{ml}$ of the diluted cell 
suspension (approximately 10,000 cells) was added. After $24 \mathrm{hrs,}$ when a partial monolayer was formed, the supernatant was flicked off, washed the monolayer once with medium and $100 \mathrm{ml}$ of different test concentrations of test drugs were added on to the partial monolayer in microtitre plates. The plates were then incubated at $37^{\circ} \mathrm{C}$ for 3 days in $5 \% \mathrm{CO}_{2}$ atmosphere, and microscopic examination was carried out and observations were noted every $24 \mathrm{hrs}$ interval. After $72 \mathrm{hrs}$, the drug solutions in the wells were discarded and $50 \mathrm{ml}$ of MTT in PBS was added to each well. The plates were gently shaken and incubated for $3 \mathrm{hrs}$ at $37^{\circ} \mathrm{C}$ in $5 \% \mathrm{CO}_{2}$ atmosphere. The supernatant was removed and $100 \mathrm{ml}$ of propanol was added, and the plates were gently shaken to solubilize the formed formazan. The absorbance was measured using a microplate reader at a wavelength of $540 \mathrm{~nm}$. The percentage growth inhibition was calculated using the following formula and concentration of test drug needed to inhibit cell growth by $50 \%\left(\mathrm{CTC}_{50}\right)$ values is generated from the dose-response curves for each cell line.

$\%$ Growth Inhibition=

$100-\left(\begin{array}{l}\text { Mean OD of individual test group } \\ \frac{- \text { Mean ODof individualgroup }}{\text { Mean ODof controlgroup }} \times 100\end{array}\right)$

\section{RESULTS}

MTT assay revealed the cytotoxic activities of stem extracts in different solvents against HeLa and MDA MB 231 cell lines. Among the three different solvents used at different concentrations, the chloroform extracts of all three Cassia species exhibited maximum cytotoxicity (\%) against both HeLa and MDA MB 231 cell lines. C. glauca chloroform extracts showed maximum inhibition against HeLa (85.17\%) and MDA MB cell lines $(78.03 \%)$ followed by pet ether extracts $(66.15 \%$ and $60.64 \%$ ) at $1000 \mathrm{mcg} / \mathrm{ml}$ (Fig. 1).

C. obtusifolia chloroform extracts showed the highest cytotoxicity against HeLa $(59.98 \%$ and $51.46 \%$ at 1000 and $500 \mathrm{mcg} / \mathrm{ml}$, respectively) and breast cancer cell lines $(66.00 \%$ and $55.17 \%$ at 1000 and $500 \mathrm{mcg} / \mathrm{ml}$, respectively). The pet ether extracts C. Obtusifolia did not show significant cytotoxicity against both HeLa and breast cancer cell lines at $1000 \mathrm{mcg} / \mathrm{ml}$.

C. sophera chloroform extracts exhibited high cytotoxicity against HeLa (70.78\%) and breast cancer cell lines $(69.27 \%)$ at $1000 \mathrm{mcg} / \mathrm{ml}$ concentration. The pet ether extracts of $C$. sophera showed moderate cytotoxicity against HeLa (39.65\%) and breast cancer cell lines (44.08\%) (Fig. 1).

The $\mathrm{CTC}_{50}$ values revealed the cytotoxic potential of $C$. glauca chloroform extracts against HeLa cell line and breast cancer cell lines with $\mathrm{CTC}_{50}$ values $180.00 \pm 3.0$ and $146.67 \pm 0.5$, respectively. The pet ether extracts of $C$. glauca also exhibited the cytotoxicity against HeLa breast cancer cell lines with values $750.00 \pm 1.2$ and $646.67 \pm 0.5$, respectively. Only chloroform extracts of $C$. Obtusifolia and $C$. sophera showed maximum activity against HeLa $(380.00 \pm 1.1$ and $800.00 \pm 1.7$, respectively) and breast cancer cell lines $(310.00 \pm 1.1$ and $633.33 \pm 0.6$, respectively (Table 1 and Fig. 2).
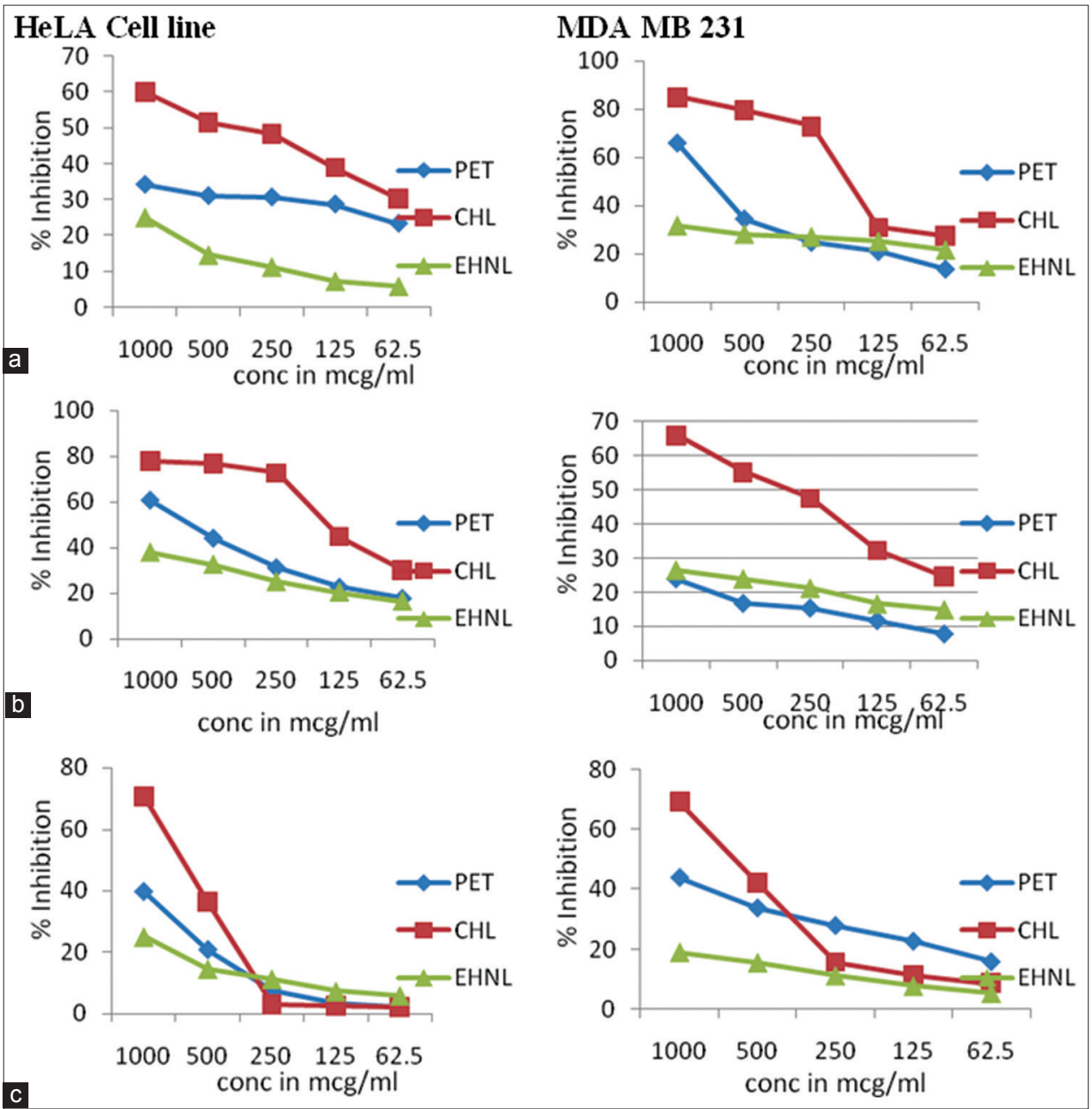

Fig. 1: Cytotoxicity (\%) of plant extracts against HeLa and MDA MB 231 cell lines at different concentrations. (a) Cassia glauca, (b) Cassia obtusifolia, (c) Cassia sophera. ${ }^{*} \mathrm{P}<0.05$ The results represents the mean $\pm \mathrm{SEM}(\mathrm{n}=3)$ 


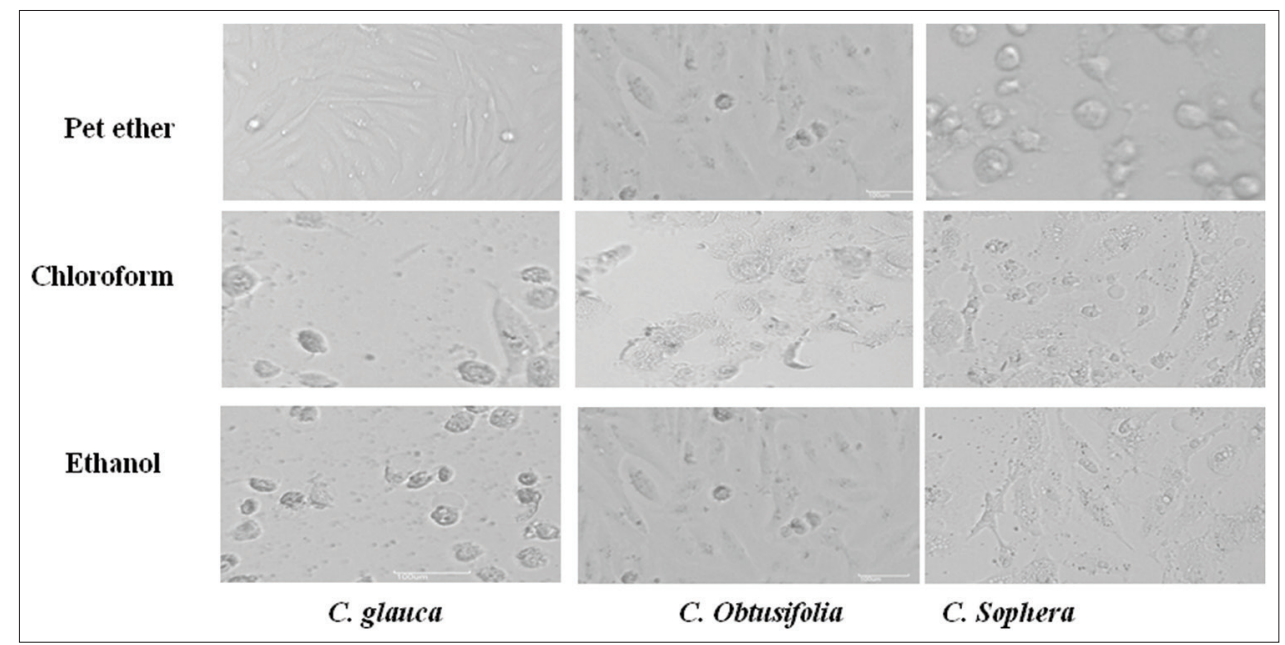

Fig. 2: Photographs showing activity against MDA MB 231 cell lines at 1000 concentration in $\mathrm{mcg} / \mathrm{ml}$

Table 1: The $\mathrm{CTC}_{50}(\mu \mathrm{g} / \mathrm{ml})$ values of Cassia species against HeLa and MDA MB 123 cell lines

\begin{tabular}{llll}
\hline \multirow{2}{*}{ Plant } & Extract & $\mathbf{C T C}_{\mathbf{5 0}}(\boldsymbol{\mu g} / \mathbf{m l})$ & \\
\cline { 3 - 4 } & & $\mathbf{H e L a}$ & MDA \\
\hline Cassia glauca & Pet ether & $=750.00 \pm 1.2$ & $646.67 \pm 0.5$ \\
& Chloroform & $=180.00 \pm 3.0$ & $146.67 \pm 0.5$ \\
Cassia obtusifolia & Ethanol & $>1000 \pm 0.00$ & $>1000$ \\
& Pet ether & $>1000 \pm 0.00$ & $>1000$ \\
& Chloroform & $=380.00 \pm 1.1$ & $310.00 \pm 1.1$ \\
Cassia sophera & Ethanol & $>1000 \pm 0.00$ & $>1000$ \\
& Pet ether & $>1000 \pm 0.00$ & $>1000$ \\
& Chloroform & $=800.00 \pm 1.7$ & $633.33 \pm 0.6$ \\
& Ethanol & $>1000 \pm 0.00$ & $>1000 \pm 0.00$ \\
\hline
\end{tabular}

$* P<0.05$ Results are means of \pm SD of three independent experiments.

SD: Standard deviation

\section{DISCUSSION}

The MTT assay revealed the cytotoxic potential of extracts against HeLa and breast cancer cell lines. A number of studies on Cassia species revealed the presence of phenols, flavonoids in the plant material [10]. The phytochemical studies of Cassia species have provided their ethnopharmtment of various diseases due to their contents of hydroxyl anthraquinone [11]. Pharmacognostical study on C. obtusifolia revealed the presence of tannins, flavonoids, steroids, and phylobatannins [12]. Similarly, ethanolic extracts of $C$. sophera proved to be hepatoprotective against carbon tetrachloride induced hepatic damage in rats [13]. In a recent study, the hexane extracts of the Cassia alata showed remarkable cytotoxicity against breast and lung carcinoma cells and the elucidation of hexane extracts revealed the presence of polyunsaturated fatty acids esters [14]. In our study, the chloroform extracts exhibited maximum cytotoxicity against the cell lines in all the plant studied. Different extracts of the plant exhibit different activity on different cell lines. This selectivity could be due to the sensitivity of the cell lines to the active compounds in the extract or to tissue-specific response [15]. However, further work is needed in the form of phytochemical screening and pharmacological activity of some more extracts about the therapeutic potential of these extracts.

\section{REFERENCES}

1. Graham JG, Quinn ML, Fabricant DS, Farnsworth NR. Plants used against cancer - An extension of the work of Jonathan Hartwell. J Ethnopharmacol 2000;73(3):347-77.

2. Cragg GM, Grothaus PG, Newman DJ. Impact of natural products on developing new anti-cancer agents. Chem Rev 2009;109(7):3012-43.

3. Newman DJ, Cragg GM. Natural product scaffolds as leads to drugs. Future Med Chem 2009;1(8):1415-27.

4. Jain R, Jain SK. Screening of in vitro cytotoxic activity of some medicinal plants used traditionally to traeat cancer in Chattisgharh state, India. Asian Pac J Trop Biomed 2011;1:S147-50.

5. Cha S. Potential anticancer medicinal plants. A statistical evaluation of their frequencies of appearance in oriental medicine formularies. Korean J Pharmacogn 1977;8:14.

6. Gupta SK.Apocynaceous plants of Varanasi with notes on their medicinal importance. J Res Indian Med Yoga Homeopath 1978;14:140-2.

7. Moriyama H, Iizuka T, Nagai M, Murata Y. HPLC quantification of kaempferol-3-O-gentiobioside in Cassia alata. Fitoterapia 2003;74(5):425-30.

8. Mohammed MM, El-Souda SS, El-Hallouty SM, Kobayashi N. Antiviral and cytotoxic activities of anthraquinones isolated from Cassia roxburghii Linn. Leaves. Herba Pol 2013;59(4):34-44.

9. Yadav JP, Arya V, Yadav S, Panghal M, Kumar S, Dhankhar S. Cassia occidentalis L: A review on its ethnobotany, phytochemical and pharmacological profile. Fitoterapia 2010;81(4):223-30.

10. Abo KA, Lasaki SW, Adeyemi AA. Laxative and antimicrobial properties of Cassia species growing in Ibadan. Niger J Nat Prod Med 1999;3(1):47-50.

11. Edeoga HO, Okwu DE, Mbaebie BO. Phytochemical constituents of some Nigerian medicinal plants. Afr J Biotechnol 2005;4(7):685-8.

12. Sudi IY, Ksgbiya DM, Muluh EK, Clement A. Nutritional and phytochemical screening of Senna obtusifolia indigenous to Mubi, Nigeria. Adv Appl Sci Res 2011;2(3):432-7.

13. Mondal A, Karan SK, Singha T, Rajalingam D, Maity TK. Evaluation of hepatoprotective effect of leaves of Cassia sophera Linn. Evid Based Complement Alternat Med 2012;2012:436139.

14. Olarte EI, Herrera AA, Villaseñor IM, Jacinto SD. In vitro antitumor properties of an isolate from leaves of Cassia alata L. Asian Pac J Cancer Prev 2013;14(5):3191-6.

15. Kirana C, Record I, McIntosh G, Jones G. Screening for antitumour activity of 11 species of Indonesian Zingeberaceae using human MCF7 and HT29 cancer cells. Pharm Biol 2003;41(4):271-6. 